\title{
PARTIAL REPLACEMENT OF CEMENT AND FINE AGGREGATE BY USING FLY ASH AND GLASS AGGREGATE
}

\author{
T. Phani Madhavi ${ }^{1}$, V.Sampathkumar ${ }^{2}$, P.Gunasekaran ${ }^{3}$ \\ ${ }^{1}$ Assistant Professor, ${ }^{2}$ Professor, ${ }^{3}$ Student, Department of Civil Engineering, Sathyabama University, Chennai, \\ Tamilnadu, India, talasilamadhavi@gmail.com
}

\begin{abstract}
Glass is a transparent material produced by melting a mixture of materials such as silica, soda ash and Calcium carbonate at high temperature followed by cooling during which solidification occurs without crystallization. Glass is a unique inert material that could be recycled many times without changing its chemical properties. Using glass in concrete is an interesting possibility for economy on wastage disposals. The inclusion of fly ash in glass concrete reduces the alkali silica reaction and improves the workability and durability properties of concrete. Sheet glass aggregate used in concrete making leads to green environment.

The objective of Present work is to find out the effectiveness of the fly ash and glass aggregate based concrete. In this investigation it was proposed that the use fly ash as cement replacement material and glass aggregate as fine aggregate material partially in concrete. Natural sand was partially replaced (10\% 20\% 30\%) with sheet glass aggregate. Compressive strength of cubes at 3days, 7 days and 28 days of duration were studied. Fineness modulus, specific gravity, moisture content, water absorption was also studied. Based on the test results, the ideal percentage of mix which shows maximum compressive strength was identified.
\end{abstract}

Keywords: Fly ash, Glass aggregate, Concrete Mix

\section{INTRODUCTION}

During recent years here awareness is increased regarding environmental pollution due to domestic and industrial waste. Now pollution control board is formed to regulate environmental degradation due to industrial waste. When once environment is allowed to degrade, it will take huge amount of public exchequers to clean it so in view of this, it is better to present than searching of solution for concrete.

Concrete is in general, cement-based concrete, which meets special performance requirement with regard to workability, strength and durability, that cannot always be obtained with techniques and materials adopted for producing conventional cement concrete. Fine aggregate is important construction material, which is widely used, in construction works. Nowadays the cost of concrete is increased since the cost of fine aggregate is increased. To reduce the requirements and cost of concrete some alternative materials are needed to replace the fine aggregate.

\subsection{Glass Concrete}

Glass is a unique inert material that could be recycled many times without changing its chemical properties. A major concern regarding the use of glass in concrete is the chemical reaction that takes place between silica-rich glass particles and the alkali in the pore solution of concrete, i.e., alkali-silica reaction. This reaction can be very detrimental to the stability of concrete, unless appropriate precautions are taken to minimize its effects. Such preventive actions could be achieved by incorporating a suitable Puzzolonic material such as fly ash, silica fume, or ground blast furnace slag in the concrete mix at appropriate proportions. Soda lime glass of < 100 mesh was effective against alkali-silica reaction. The most widely used fine aggregate for the making of concrete is the natural sand mined from the riverbeds. However the availability of river sand for the preparation of concrete is becoming scarce due to the excessive nonscientific methods of mining from the riverbeds, lowering of water table, sinking of the bridge piers, etc. are becoming common treats. The present scenario demands identification of substitute materials for the river sand for making concrete. Recently, some attempts have been made to use ground glass as a replacement in concrete. The objective of this paper is to present the results of experimental investigations on physical and mechanical properties of concrete made with sheet glass powder concrete. Natural fine aggregate is substituted by weight by sheet glass powder at rates varying from $10,20,30,40$ and 50 percentages. Compressive, tension, and flexural strength are evaluate and compared up to 180 days of ages.

Glass is widely used in our lives through manufactured products such as sheet glassware, glass, bottles, and vacuum tubing. Glass is an ideal material for recycling. The use of recycled glass in new container helps save of energy. The amount of waste glass is gradually increased over the recent 
years due to an ever growing use of glass products. When waste glasses are reused in making concrete products, the production cost of concrete will go down. Crushed glass or cullet, if properly sized and processed, can exhibit characteristics application to that of gravel or sand.

However, deleterious alkali-silica reaction might occur in glass concrete due to its high silica constituent. Some solutions have been formed to alleviate alkali-silica reaction, but these solutions have some limitations which made it still particularly important to investigate the utilization of glass in concrete. The limitations include the long-term inspecting of the effectiveness of alkali-silica reaction suppressants.

\subsection{Fly Ash:}

The abundant production of fly ash from coal based thermal power plants as waste products becoming problem for their disposal and it is also hazardous to the environment. The inclusion of fly ash in glass fiber reinforced concrete reduces the environmental pollution and improves the workability and durability properties of concrete. In the present experimental investigation glass fibers in different volume fractions with $25 \%$ and $40 \%$ replacement of cement by fly ash has been used to study the effect on compressive strength, split tensile strength, flexural strength of concrete. For each mix standard sizes of cubes, cylinders and prisms as per Indian Standards were cast and tested for compressive strength, split tensile strength and flexural strength at age of 7 days and 28 days as per Indian Standards.

Cement with Puzzolona like fly ash reduce the permeability of concrete and dense calcium silicate hydrate. Fly ash is a byproduct of the thermal power plants. Usually, Class F fly ashes have a lower content of $\mathrm{Cao}$ and exhibit Puzzolonic properties.

\section{MATERIALS AND EXPERIMENTAL METHODOLOGY}

In the present work, various materials like Flyash, Cement, Glass aggregate, Coarse aggregate, Fine aggregate, Water were used. It was found that the Specific gravity and Finness modulus of fine aggregate $(G)$ was 2.66 and 2.892 respectively. It was found that the specific gravity, Finness modulus and average water absorption of course aggregate was $2.936,8.10$ and 2.7 respectively. From the experimental results it was found that the specific gravity, Initial setting time, Final setting time of cement was 2.88, 75 minutes, and 250minutes respectively. The Finness modulus of glass aggregate was 3.51 .

\subsection{Mix Design for $M_{30}$ Grade}

\section{a. Design Stipulations:}

Characteristic compressive strength required in field at 28 days is $30 \mathrm{~N} / \mathrm{mm} 2$; Maximum size of aggregate is $20 \mathrm{~mm}$ (angular);Degree of workability is 0.90C.F; Degree of quality control is Good; Type of exposure is Mild

\section{b. Test Data for Materials:}

Specific gravity for cement is 3.01; Specific gravity of Coarse aggregate is 2.85and Fine aggregate is 2.66; Water absorption for Coarse aggregate is $2.7 \%$ and for Fine aggregate is $1.0 \%$

\section{c. Design}

Target Mean Strength of Concrete---Assumed standard deviation as per IS 456-2000 referring the table (6) is $S=6$

Target mean strength $=\mathrm{fck}+\mathrm{ts}=30+1.65(6)=39.9$ $\mathrm{N} / \mathrm{mm}^{2}$

\section{d .Selection of Water Cement Ratio:}

For Target mean strength $=39.9 \mathrm{~N} / \mathrm{mm}^{2}$;

From figure $\mathrm{W} / \mathrm{C}$ ratio $=0.375$

\section{e. Selection of Water and Sand Content:}

For aggregate size $20 \mathrm{~mm}$, water content including surface water, per cubic meter of concrete is $186 \mathrm{~kg}$.

Sand content as percentage of total aggregate of absolute volume is $35 \%$

Table 1 Selection of water and sand content

\begin{tabular}{|l|c|c|}
\hline \multirow{2}{*}{ Change in condition } & \multicolumn{2}{|c|}{ Adjustment required } \\
\cline { 2 - 3 } & $\begin{array}{c}\text { Water } \\
\text { content }\end{array}$ & $\begin{array}{c}\text { Sand in total } \\
\text { aggregate }\end{array}$ \\
\hline $\begin{array}{l}\text { For decrease in w/c } \\
\text { ratio by (0.6- } \\
0.375=0.225)\end{array}$ & 0 & -4.5 \\
\hline $\begin{array}{l}\text { For increase in } \\
\text { compacting } \\
\text { factor(0.9-0.8=0.1) }\end{array}$ & +3 & 0 \\
\hline $\begin{array}{l}\text { For sand conforming } \\
\text { to zone II }\end{array}$ & 0 & -1.5 \\
\hline & $+3 \%$ & $-6 \%$ \\
\hline
\end{tabular}

From Table 1, required sand content as $\%$ of total aggregate by absolute volume $=35-6=29 \%$

Required water content $=186+\frac{186 \times 3}{100}=191.6 \mathrm{~kg} / \mathrm{m}^{3}$ 


\section{f. Determination of Cement Content:}

Water cement ratio $\quad=0.375$

Water $\quad=191.6$ lit

Cement

$$
=\frac{191.6}{0.375}=510.96 \mathrm{~kg} / \mathrm{m}^{3}
$$

\section{g. Determination of Coarse and Fine Aggregate}

\section{Content:}

Fine Aggregate:

$$
\mathrm{V}=\left\{\mathrm{w}+\frac{c}{s_{c}}+\frac{1}{p} \frac{f_{a}}{s_{f a}}\right\} \times \frac{1}{1000}
$$

Fine aggregate $\quad=520 \mathrm{~kg} / \mathrm{m}^{3}$
Coarse Aggregate:

$$
\mathrm{V}=\left\{\mathrm{w}+\frac{c}{s_{c}}+\frac{1}{1-p} \frac{C_{a}}{s_{C a}}\right\} \times \frac{1}{1000}
$$

Coarse aggregate $=1208 \mathrm{~kg} / \mathrm{m}^{3}$

\section{h. Mix Proportion:}

$\begin{array}{cccc}\text { Water: } & \text { Cement: } & \text { FA: } & \text { CA } \\ 191.6 & 511 & 520 & 1208 \\ 0.5 & 1 & 1.02 & 2.36\end{array}$

The Mix proportion was given in Table 2

Table 2 Mix Proportion

\begin{tabular}{|c|c|c|c|c|c|c|}
\hline $\begin{array}{c}\text { Fly } \\
\text { ash } \\
\mathbf{\%}\end{array}$ & $\begin{array}{c}\text { Replacement of } \\
\text { Fine aggregate \% }\end{array}$ & $\begin{array}{c}\text { Cement } \\
(\mathbf{k g})\end{array}$ & $\begin{array}{c}\text { Fine aggregate } \\
\mathbf{( k g )}\end{array}$ & $\begin{array}{c}\text { Coarse aggregate } \\
(\mathbf{k g})\end{array}$ & $\begin{array}{c}\text { Fly ash } \\
(\mathbf{k g})\end{array}$ & $\begin{array}{c}\text { Glass } \\
\text { aggregate } \\
(\mathbf{k g})\end{array}$ \\
\hline 0 & 0 & 16.641 & 16.974 & 39.273 & - & - \\
\hline 0 & 10 & 16.641 & 15.277 & 39.273 & - & 1.697 \\
\hline 0 & 20 & 16.641 & 13.579 & 39.273 & - & 3.395 \\
\hline 0 & 30 & 16.641 & 11.882 & 39.273 & - & 5.092 \\
\hline 10 & 0 & 14.977 & 16.974 & 39.273 & 1.664 & - \\
\hline 10 & 10 & 14.977 & 15.277 & 39.273 & 1.664 & 1.697 \\
\hline 10 & 20 & 14.977 & 13.579 & 39.273 & 1.664 & 3.395 \\
\hline 10 & 30 & 14.977 & 11.882 & 39.273 & 1.664 & 5.092 \\
\hline 20 & 0 & 13.313 & 16.974 & 39.273 & 3.328 & - \\
\hline 20 & 10 & 13.313 & 15.277 & 39.273 & 3.328 & 1.697 \\
\hline 20 & 20 & 13.313 & 13.579 & 39.273 & 3.328 & 3.395 \\
\hline 20 & 30 & 13.313 & 11.882 & 39.273 & 3.328 & 5.092 \\
\hline 30 & 0 & 11.649 & 16.974 & 39.273 & 4.992 & - \\
\hline 30 & 10 & 11.649 & 15.277 & 39.273 & 4.992 & 1.697 \\
\hline 30 & 20 & 11.649 & 13.579 & 39.273 & 4.992 & 3.395 \\
\hline 30 & 30 & 11.649 & 11.882 & 39.273 & 4.992 & 5.092 \\
\hline
\end{tabular}

\subsection{Compressive Strength Test:}

The steel mould of size $150 \times 150 \times 150 \mathrm{~mm}$ is well tightened and oiled thoroughly. The fresh mixed concrete is placed and well compacted through mechanical vibrators and after 24 hours they were allowed for curing in a period of 3, 7, 28 days and they were tested. After the curing period the specimen is taken out from the curing tank and wipes it clean. The dimensions of the specimens and the weight of the specimens were noted down with accuracy. Then the specimen is placed between the loading the surface of the CTM and the load is applied till the specimen fails. The ultimate load at the time of failure is noted down. The test procedures were adopted as per
ASTM standards. The load was applied at the rate of 140 $\mathrm{kg} / \mathrm{cm}^{2} / \mathrm{min}$ till the cube breaks.

\section{RESULTS AND DISCUSSIONS}

\subsection{Analysis:}

A laboratory study were performed to determine the compressive strengths 144 cubes for 3 days, 7 days, 28 days of casting of different trail of concrete with $0,10,20,30$ percent replacement of cement by fly ash and $0,10,20,30$ percent replacement of fine aggregate by glass aggregate. The various test results are analyzed below. 


\subsection{Compressive Strength:}

The compression test was performed as per formed as per Indian Standard specifications. From the test the average stresses values taken accordingly. The test results are shown in Table 3
Compressive Strength $=$ Compressive Load/Cross Sectional Area in $\mathrm{N} / \mathrm{mm}^{2}$

Based on the test results obtained from the compressive strength test on 3days, 7days, and 28days, the graph between Mix No. Vs Compressive strength was shown in Fig 1,Fig 2 and Fig 3 respectively

Table 3 Determination of Compressive Strength

\begin{tabular}{|c|c|c|c|c|c|c|}
\hline \multirow[t]{2}{*}{ Mix } & \multirow{2}{*}{$\begin{array}{c}\text { Partial } \\
\text { replacement of } \\
\text { cement by fly ash } \\
\%\end{array}$} & \multirow{2}{*}{$\begin{array}{c}\text { Partial replacement of } \\
\text { sand by glass } \\
\text { aggregate } \%\end{array}$} & \multirow{2}{*}{$\begin{array}{c}\text { Workability } \\
\text { Slump value in } \\
\mathrm{cm}\end{array}$} & \multicolumn{3}{|c|}{ Compressive strength $\mathrm{N} / \mathrm{mm}^{2}$} \\
\hline & & & & 3 days & 7 days & 28 days \\
\hline 1 & - & - & - & 24.57 & 29.77 & 41.99 \\
\hline 2 & - & 10 & - & 24.30 & 31.55 & 42.82 \\
\hline 3 & - & 20 & - & 25.78 & 32.00 & 43.26 \\
\hline 4 & - & 30 & - & 24.89 & 30.85 & 42.37 \\
\hline$\overline{5}$ & 10 & - & - & 26.09 & 26.22 & 43.26 \\
\hline 6 & 10 & 10 & - & 26.67 & 28.00 & 43.41 \\
\hline 7 & 10 & 20 & - & 27.56 & 30.22 & 43.73 \\
\hline 8 & 10 & 30 & - & 26.67 & 28.00 & 43.23 \\
\hline$\overline{99}$ & 20 & - & - & 25.62 & 26.67 & "42.37 \\
\hline 10 & 20 & 10 & - & 24.58 & 28.44 & 42.57 \\
\hline 11 & 20 & 20 & - & 26.67 & 33.78 & 38.52 \\
\hline 12 & 20 & 30 & 1 & 25.70 & 27.70 & 36.00 \\
\hline 13 & 30 & - & 2 & 23.70 & 25.33 & 31.99 \\
\hline 14 & 30 & 10 & 2 & 20.44 & 25.78 & 32.15 \\
\hline 15 & 30 & 20 & 3 & 20.00 & 24.74 & 32.44 \\
\hline 16 & 30 & 30 & 5 & 18.52 & 21.33 & 27.56 \\
\hline
\end{tabular}

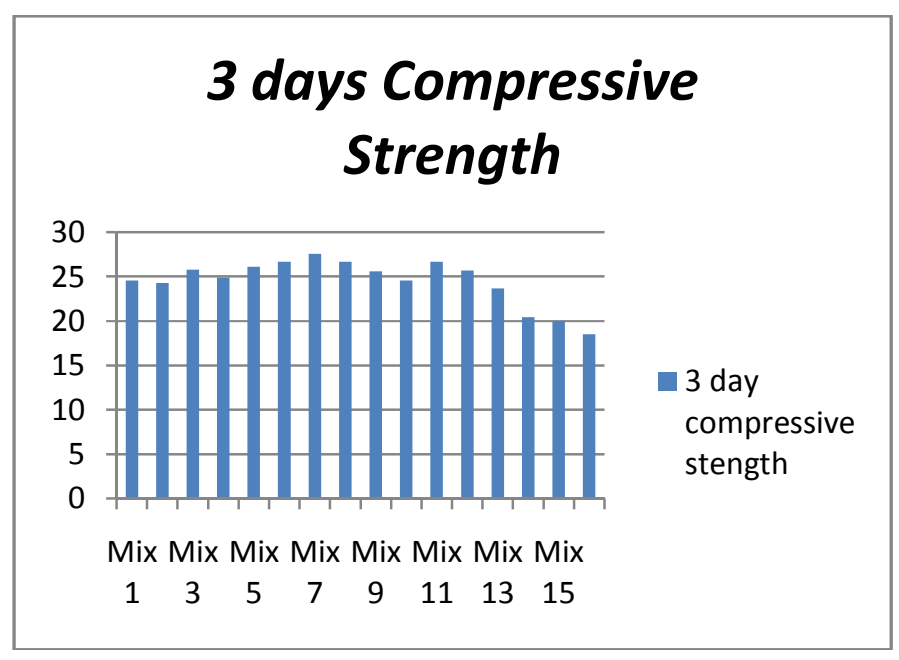

Fig.1 Compressive strength on 3 days

\section{7 days Compressive Strength}

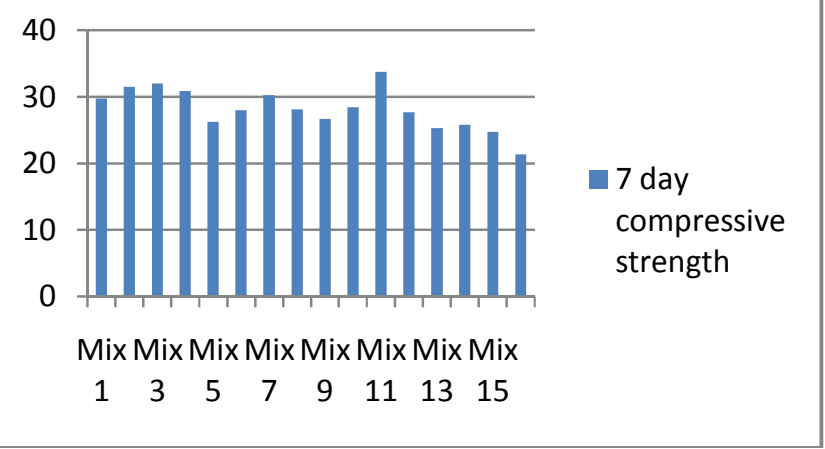

Fig.2 Compressive strength on 7 days 


\section{8 days Compressive Strength}

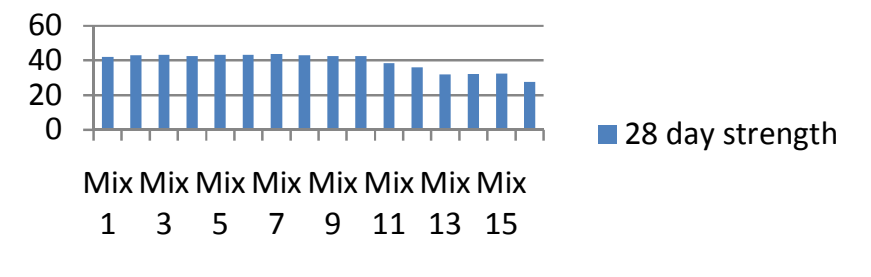

Fig.3 Compressive strength on 28 days

\section{CONCLUSIONS}

- In $1^{\text {st }}$ set of cubes, the maximum compressive strength obtained for 28 days is $43.26 \mathrm{~N} / \mathrm{mm}^{2}$ with the replacement of $0 \%$ of Cement by fly ash and $20 \%$ of fine aggregate by glass aggregate.

- In $2^{\text {nd }}$ set of cubes, the maximum compressive strength obtained for 28 days is $43.73 \mathrm{~N} / \mathrm{mm}^{2}$ with the replacement of $10 \%$ of Cement by fly ash and $20 \%$ of fine aggregate by glass aggregate.

- In $3^{\text {rd }}$ set of cubes, the maximum compressive strength obtained for 28 days is $42.57 \mathrm{~N} / \mathrm{mm}^{2}$ with the replacement of $20 \%$ of Cement by fly ash and $10 \%$ of fine aggregate by glass aggregate.

- $\quad$ iv)In $4^{\text {th set }}$ of cubes, the maximum compressive strength obtained for 28 days is $32.44 \mathrm{~N} / \mathrm{mm}^{2}$ with the replacement of $30 \%$ of Cement by fly ash and $20 \%$ of fine aggregate by glass aggregate.

- So, the mix No.7 in $2^{\text {nd }}$ set of cubes is concluded as economical and ideal mix based on the results obtained.

\section{REFERENCES}

[1] Alidoust .O, Sadrinejad .I, and Ahmadi .M. A. "A Study on Cement-Based Composite Containing Polypropylene Fibers and Finely Ground Glass Exposed to Elevated Temperatures" World Academy of Science, Engineering and Technology, 2007 ,pages $162-167$

[2] Ahmad Shayan "Value-added Utilisation of Waste Glass in Concrete" IABSE Symposium Melbourne, 2002, pages 1-11

[3] Mageswari .M and Dr. Vidivelli .B "The Use of Sheet Glass Powder as Fine Aggregate Replacement in Concrete" The Open Civil Engineering Journal, Vol 4, 2010 , pages 65-71

[4] Rama Mohan Rao .P, Sudarsana Rao .H, Sekar .S. K. "Effect of Glass Fibres on Flyash Based Concrete" International journal of civil and structural engineeringVol 1, No 3, 2010, pages 606-612
[5] Turgut .P, Yahlizade .E. S. "Research into Concrete Blocks with Waste Glass" International journal of civil and environmental engineering 1:4, 2009,pages 203209

[6] IS 456 - 2000 - Indian Standard Code of Practice for plain and Reinforced Concrete

[7] IS 10262 - 2009 Indian Standard recommended guideline for concrete mix design

[8] IS 383-1970- specification for coarse and fine aggregate from natural source for concrete

[9] IS 8112-1989-43 grade opc Specification 